\title{
WATER AND SOIL PHYSICOCHEMICAL CHARACTERISTICS OF DIFFERENT RICE CULTIVATION AREAS
}

\author{
HARUN, N. S. ${ }^{1}$ - HANAFIAH, M. M. ${ }^{1,2^{*}}-$ NIZAM, N. U. M. ${ }^{1}$ - RASOOL, A. ${ }^{3,4}$ \\ ${ }^{I}$ Department of Earth Sciences and Environment, Faculty of Science and Technology, Universiti \\ Kebangsaan Malaysia, 43600 Bangi, Selangor, Malaysia \\ ${ }^{2}$ Centre for Tropical Climate Change System, Institute of Climate Change, Universiti \\ Kebangsaan Malaysia, 43600 Bangi, Selangor, Malaysia \\ ${ }^{3}$ Toxicology Unit, Pharmacology and Toxicology Division, CSIR-Indian Institute of Chemical \\ Technology, Hyderabad, India \\ ${ }^{4}$ Department of Environmental Sciences, Osmania University, Hyderabad 500007, India \\ ${ }^{*}$ Corresponding author \\ e-mail: mhmarlia.ukm.edu.my
}

(Received $12^{\text {th }}$ May 2020; accepted $13^{\text {th }}$ Aug 2020)

\begin{abstract}
In this study, the physicochemical characteristics of water and soil in conventional and organic rice cultivations are determined. Physicochemical parameters for water and soil samples are assessed by laboratory analysis. Chemical and physical parameters for water quality include temperature, $\mathrm{pH}$, dissolved oxygen (DO), chemical oxygen demand (COD), biochemical oxygen demand $\left(\mathrm{BOD}_{5}\right)$, total suspended solids, and heavy metals. Parameters for the physicochemical analysis of soil include $\mathrm{pH}$, particle size distribution, organic carbon, electrical conductivity (EC), cation exchange capacity, and heavy metals. Based on the water quality index, water qualities of conventional and organic rice fields are categorized into Class III. Based on the independent sample t-test, significant differences are observed between conventional rice and organic rice for $\mathrm{pH}, \mathrm{DO}, \mathrm{BOD}_{5}, \mathrm{COD}$, ammoniacal nitrogen $\left(\mathrm{NH}_{3}-\mathrm{N}\right)$, arsenic (As), chromium $(\mathrm{Cr})$, iron $(\mathrm{Fe})$, and nickel $(\mathrm{Ni})(\mathrm{p}<0.05)$. For soil samples, significant differences are observed between conventional rice and organic rice for $\mathrm{pH}$, organic matter (OM), $\mathrm{EC}, \mathrm{As}, \mathrm{Cr}, \mathrm{Fe}$, and $\mathrm{Ni}$ ( $\mathrm{p}>0.05)$. The results of this study can serve as a guideline and basis for future studies on irrigation water and soil quality in sustainable agricultural management in Malaysia.
\end{abstract}

Keywords: Malaysia, physicochemical parameters, rice production, crop management, sustainable agriculture

\section{Introduction}

Malaysia has 688,770 hectares of land for rice cultivation, which produced 2,739,606 metric tons of rice in 2016 (DOSM, 2018). Recently, the tremendous growth in the population has led to an increase in the rice productivity. The need for high rice production has led to the expansion of irrigated areas. As a result, the rice cultivation area has increased, while rice production has decreased from 2014 to 2017. Although the use of hybrid rice varieties introduced by the Malaysian Agricultural Research and Development Institute (MARDI) has overcome some of the issues, the yield is still a factor that limits the increased production level due to bad weather as well as pests and diseases (USDA, 2018). To drive the modernization of Malaysia's agro-food sector, the 
rice sector was included in one of the seven specialized industries listed by the National Agro-Food Policy (DAN) 2011-2020. DAN 2011-2020 targets to increase productivity and yields to ensure a sufficient food supply, high-value and sustainable agricultural development. By 2020, the Malaysian government also aims to achieve $80 \%$ self-sufficiency in rice (MOA, 2016). Hence, the government has provided several incentives such as subsidized seeds and fertilizers to encourage rice production.

The expansion of irrigated areas has become one of the major challenges in ensuring food security due to the high input used in rice cultivation such as water, fertilizers, and pesticides (Bouman, 2007; Hanafiah et al., 2019). With respect to these issues in rice cultivation, several methods have been explored for the application of less input in rice production, such as aerobic rice cultivation, system of rice intensification, ground-cover rice production system, raising beds, and alternate wetting and drying (Farooq et al., 2009). Moreover, organic cultivation practices have become an alternative to sustainable rice production as these practices avoid the use of synthetic fertilizers and chemical pesticides and exhibit benefits in terms of food security (Champagne et al., 2007; Keawpeng and Meenune, 2012).

Previous studies have independently reported that non-sustainable agriculture techniques can cause water quality problems (Reche et al., 2016; Banch et al., 2020; Bong et al., 2020). Water contamination in rice fields is caused by the chemical substances used for soil fertilization and pest control (Rhee et al., 2011). Iqbal (2011) has reported that pesticides do not exhibit adverse effects due to their low application amount; however, the continuous use of pesticides can slowly disturb the ecosystem and living organisms. Rice cultivation under flooded conditions causes a change in microbial activities from the aerobic to anaerobic fermentation of organic matter in rice fields. Hence, anaerobic respiration can produce substances that can cause the chemical reduction of soil components (Ethan, 2015). However, Haefele et al. (2014) have reported that some negative soil characteristics, including low nutrient reserves and an extremely low cation exchange capacity (CEC), are not considerably affected by flooding.

Water quality index (WQI) is a scale related to a group of parameters that are combined into a single number to determine the overall water quality status at a certain time and location (Yisa and Jimoh, 2010; Leščešen et al., 2015; Ashraf and Hanafiah, 2017; Hanafiah et al., 2018a, 2019). However, the water quality parameters used were varied. Meher et al. (2015) have reportedly utilized 14 parameters for determining the WQI of the Ganges River, including $\mathrm{pH}$, total dissolved solids (TDS), alkalinity, dissolved oxygen (DO), conductivity, and turbidity. On the other hand, Al-Shujairi (2013) has developed WQI to evaluate the water quality of two rivers in Iraq by utilizing seven water quality parameters of $\mathrm{pH}, \mathrm{DO}, \mathrm{TDS}$, total hardness, biochemical oxygen demand ( $\left.\mathrm{BOD}_{5}\right)$, nitrate $\left(\mathrm{NO}_{3}\right)$, and phosphate, respectively.

The physicochemical analysis of soil is another important factor in the agriculture sector for plant growth, crop nutrient management, and soil management. This assessment can aid farmers in managing the nutrient input for crops during cultivation. Several 
parameters can be employed for the monitoring of agricultural soil, including electrical conductivity (EC), soil organic matter (SOM), and heavy metal analysis. Aimrun et al. (2011) have reported that EC can provide information regarding soil texture, thereby permitting the estimation of the water content. In addition, EC can serve as a proxy for the physicochemical properties of soil, such as SOM, cation content, and CEC (Liu et al., 2011; Li et al., 2013; Wang et al., 2016, 2018). Several studies of soil in paddy fields have been conducted in Malaysia. Aimrun et al. (2011) have conducted a study regarding paddy soil properties and yield characteristics based on EC, while Khairiah et al. (2009) have conducted a study focusing on the heavy-metal content in paddy soil in Kedah. Physicochemical analysis of soil properties in rice fields can serve as a basis and reference to improve the rice cultivation process and reduce the environmental pollution in rice fields.

In recent years, as a result of increasing concerns of environmental pollution due to the application of chemical fertilizers, several efforts have been made to replace chemical fertilizers by organic fertilizers (Zhao et al., 2015; Lenka et al., 2016). Previously, Jat et al. (2015), Singh et al. (2017), and Thakur et al. (2016) have independently reported that organic rice cultivation increases rice production. However, the environmental impact also should be emphasized while simultaneously aiming for high rice productivity to ensure environmental sustainability. Currently, only a few studies on the impact of conventional and organic rice cultivations on the environment in Malaysia have been conducted. Accordingly, it is imperative to conduct a performance evaluation study on the physicochemical characteristics of water and soil for the purpose of increasing the rice yield and sustaining its production to meet the requirements in Malaysia. Hence, this paper aims to determine the physicochemical properties of water and soil for conventional and organic rice cultivations.

\section{Materials and Methods}

\section{Samples collection and preservation}

The water and soil samples were collected at Sabak Bernam, Selangor, Malaysia, from conventional and organic rice fields $\left(3.684153^{\circ} \mathrm{N}, 101.022841^{\circ} \mathrm{E}\right)$ (Figure 1). Soil and water samples were collected from six sampling stations consists of conventional and organic rice fields. In total, 18 sampling points were included in the analysis. Water and soil samples were placed in polyethylene bottles and plastic bags, respectively. Water samples were preserved at $4-5^{\circ} \mathrm{C}$ to minimize biological activity and chemical changes. Soil samples were dried at room temperature in the laboratory before analysis was conducted. For $\mathrm{BOD}_{5}$ tests, samples were collected using glass bottles wrapped with an aluminum foil to avoid the penetration of sunlight into the bottles. Samples for heavy metal tests were placed in different $50-\mathrm{mL}$ polyethylene bottles. Samples were acidified to a $\mathrm{pH}$ less than 2 by the addition of $\mathrm{HNO}_{3}$ to the samples. All samples that could not be analyzed immediately in the field were preserved following the method recommended by 
GEMS (1978) and were transported to the laboratory within $24 \mathrm{~h}$ of sampling. Table 1 summarizes the description of each sampling station.
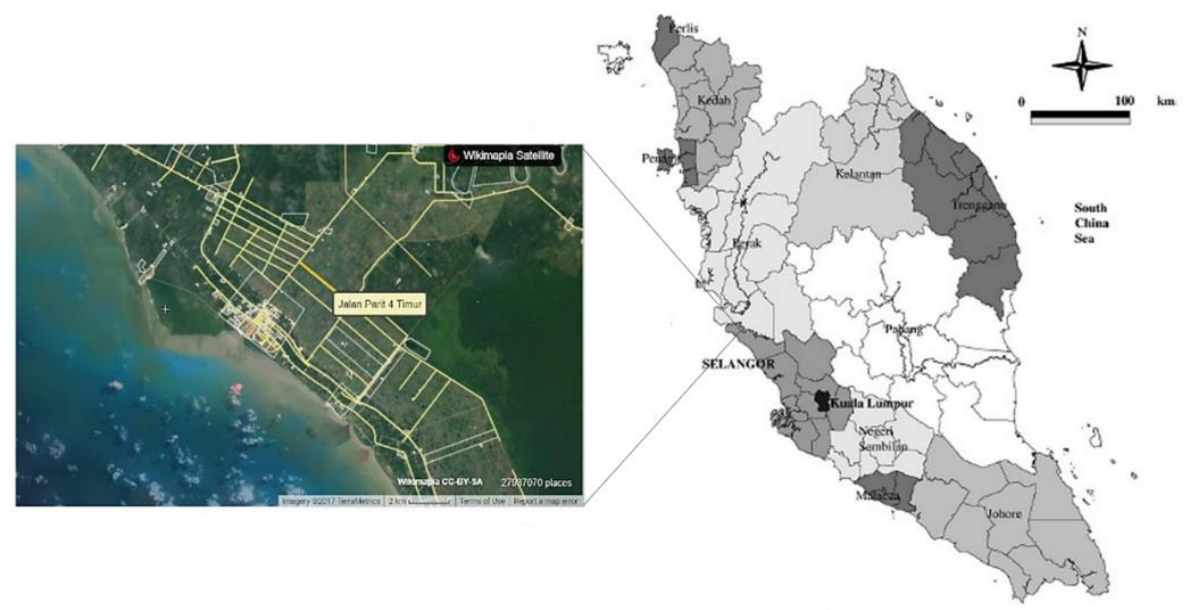

Figure 1. Location of conventional and organic rice fields for water and soil sampling

Table 1. Description of each sample based on the sampling station

\begin{tabular}{|c|c|}
\hline Sampling station & Description \\
\hline $\mathrm{S} 1 ; \mathrm{P} 3$ & Located at the inlet of conventional rice field. \\
\hline $\mathrm{S} 2 ; \mathrm{P} 2$ & $\begin{array}{l}\text { Located at the conventional rice field. There are paddy planting activities occurred such } \\
\text { as fertilizing and pesticide application. }\end{array}$ \\
\hline $\mathrm{S} 3 ; \mathrm{P} 3$ & Sampling was done at the outlet of conventional rice field. \\
\hline $\mathrm{T} 1 ; \mathrm{Q} 1$ & Located at the inlet of organic rice field. \\
\hline T2; Q2 & $\begin{array}{l}\text { Located at the middle of organic rice field. There are organic paddy planting activities } \\
\text { occurred such as application of effective microbes. }\end{array}$ \\
\hline T3; Q3 & Located at the outlet of organic rice field. \\
\hline
\end{tabular}

$\mathrm{S}=$ represent water samples in the conventional rice field, $\mathrm{T}=$ represent water samples in the organic rice field, $\mathrm{P}=$ represent soil samples in the conventional rice field, $\mathrm{Q}=$ represent soil samples in the organic rice field

Water quality was analyzed according to temperature, $\mathrm{pH}, \mathrm{DO}, \mathrm{BOD}_{5}, \mathrm{COD}$, ammoniacal nitrogen, total suspended solid (TSS), and heavy metals. DO values, water temperature, and $\mathrm{pH}$ values were measured in situ using a YSI Model 556 Multi Probe system. COD, TSS, $\mathrm{BOD}_{5}$, and ammoniacal nitrogen were analyzed in the laboratory following American Public Health Associations Standard (APHA, 1998) standard procedures. Table 2 summarizes the parameters, methodology, and instruments used in this study. 
Table 2. Parameters, applied methodologies, and instruments used in this study for the physicochemical analysis of water and soil

\begin{tabular}{|c|c|c|}
\hline Parameters & Methodology & Instrument \\
\hline \multicolumn{3}{|c|}{ Water analysis } \\
\hline Temperature & - & YSI Pro2030 DO Meter \\
\hline $\mathrm{pH}$ & - & pH meter HI8424 \\
\hline Dissolved oxygen (DO) & - & YSI Pro2030 DO Meter \\
\hline Bio-chemical oxygen demand (BOD5) & $\mathrm{BOD}_{5}$ & YSI 5000 Dissolved Oxygen meter \\
\hline Chemical oxygen demand (COD) & Closed reflux & \\
\hline Ammoniacal nitrogen & Direct Nesslerization & Hach DR 6000 spectrophotometer \\
\hline Total suspended solid (TSS) & Photometric & \\
\hline Heavy metals & EPA Method 200.8 & $\begin{array}{c}\text { Inductively Coupled Plasma Mass } \\
\text { Spectrometry (ICP-MS) }\end{array}$ \\
\hline \multicolumn{3}{|c|}{ Soil analysis } \\
\hline $\mathrm{pH}$ & $\begin{array}{c}\text { Was determined in distilled water } \\
\text { with ratio 1:2.5 of soil: distilled } \\
\text { water }\end{array}$ & pH meter (DELTA 320 model) \\
\hline Organic matter & $\begin{array}{c}\text { Gravimetric method based on loss } \\
\text { on ignition }\end{array}$ & Oven, furnace, weighting scale \\
\hline Electrical conductivity & $\begin{array}{l}\text { Was determined in saturated } \\
\text { extract of gypsum }\end{array}$ & EC meter Model H 18819 Hanna \\
\hline Particle size distribution & $\begin{array}{l}\text { Pipette method together with dry } \\
\text { sieving }\end{array}$ & Sieve (ASTM) \\
\hline Cation exchange capacity & $\begin{array}{l}\text { EPA Method 9081: Sum of basic } \\
\text { cations with acidic cations through } \\
\text { summation method }\end{array}$ & $\begin{array}{l}\text { Centrifuge tube and stopper, mechanical } \\
\text { shaker, volumetric flask } 100 \mathrm{~mL}, \\
\text { Inductively coupled plasma atomic } \\
\text { emission spectroscopy (ICP-AES) }\end{array}$ \\
\hline Heavy metals & Acid digestion Method 3050B & $\begin{array}{c}\text { Inductively Coupled Plasma Mass } \\
\text { Spectrometry (ICP-MS) }\end{array}$ \\
\hline
\end{tabular}

\section{Water quality analysis}

The use of water is classified based on six classes (i.e., class I, IIA, IIB, III, IV, and V) by the Department of Environment (DOE, 2006). To determine the quality of water samples under the National Water Quality Standards for Malaysia (NWQS), WQI was calculated by the following equation $E q .1$ :

$$
\begin{gathered}
\mathrm{WQI}=(0.22 \times \mathrm{SIDO})+(0.19 \times \mathrm{SIBOD})+(0.16 \times \mathrm{SICOD})+(0.15 \times \\
\text { SIAN })+(0.16 \times \mathrm{SISS})+(0.12 \times \mathrm{SIpH})
\end{gathered}
$$


where,

SIDO $=$ SubIndex DO (\% saturation $)$,

SIBOD $=$ SubIndex BOD,

SICOD = SubIndex COD,

SIAN $=$ SubIndex SS,

$\mathrm{SIpH}=$ SubIndex $\mathrm{pH}$,

$0 \leq \mathrm{WQI} \leq 100$.

\section{Statistical analysis}

Statistical analysis was done using the statistical package for social science software (SPSS). Data for physicochemical parameters of water and soil samples were represented as mean values. Independent sample t-tests were conducted to compare the results obtained for the water quality and physicochemical analysis of soil in different rice cultivation systems.

\section{Results and discussion}

\section{Physicochemical properties of water in rice fields}

Water quality is one of the key factors in the agriculture sector that ensures the healthy growth of crops (Harun and Hanafiah, 2018a, 2018b; Hanafiah et al., 2020; Nizam et al., 2020). The Department of Environment (DOE), Malaysia, has set six parameters to calculate the National Water Quality Index (Alssgeer et al., 2018; Hanafiah et al., 2018b; Ariffin et al., 2019): pH, DO, BOD 5 , COD, ammoniacal nitrogen, and suspended solids. Table 3 summarizes the physicochemical characteristics of water in conventional and organic rice fields.

$\mathrm{pH}$ is important for determining not only if a chemical or biological reaction can occur but also the degree of toxicity of some pollutants in water (Basheer et al., 2015). All samples were slightly acidic in the range from $\mathrm{pH} 5.41 \pm 0.12$ to $5.86 \pm 0.18$ for conventional rice fields and from $\mathrm{pH} 4.24 \pm 0.13$ to $4.50 \pm 0.12$ for organic rice fields (Table 3). Based on the NWQS for Malaysia, the average $\mathrm{pH}$ for conventional rice was categorized into class III, while the average $\mathrm{pH}$ for organic rice was categorized into class IV. Hence, the average $\mathrm{pH}$ values for conventional and organic rice are within the permissible range for irrigated agriculture. Results obtained from the independent sample $t$-test revealed a significant difference between conventional and organic rice $(p<0.001)$. 
Table 3. Water analysis of conventional and organic rice fields

\begin{tabular}{|c|c|c|c|c|c|c|c|c|}
\hline \multirow{2}{*}{ Parameter } & \multicolumn{4}{|c|}{ Conventional rice } & \multicolumn{4}{|c|}{ Organic rice } \\
\hline & S1 & S2 & $\mathbf{S 3}$ & S $_{\text {average }}$ & T1 & $\mathbf{T 2}$ & T3 & $\mathbf{T}_{\text {average }}$ \\
\hline $\mathrm{pH}$ & $5.86 \pm 0.18$ & $5.41 \pm 0.12$ & $5.58 \pm 0.10$ & 5.62 & $4.24 \pm 0.13$ & $4.50 \pm 0.12$ & $4.39 \pm 0.25$ & 4.38 \\
\hline $\mathrm{DO}(\mathrm{mg} / \mathrm{L})$ & $5.70 \pm 0.22$ & $6.57 \pm 0.29$ & $4.15 \pm 0.14$ & 5.47 & $4.28 \pm 0.07$ & $5.46 \pm 0.41$ & $3.45 \pm 0.45$ & 4.40 \\
\hline $\mathrm{BOD}_{5}(\mathrm{mg} / \mathrm{L})$ & $1.16 \pm 0.32$ & $2.48 \pm 0.11$ & $1.27 \pm 0.20$ & 1.64 & $0.90 \pm 0.30$ & $1.44 \pm 0.19$ & $0.62 \pm 0.35$ & 0.99 \\
\hline $\mathrm{COD}(\mathrm{mg} / \mathrm{L})$ & $11.45 \pm 3.48$ & $29.88 \pm 0.32$ & $27.68 \pm 1.45$ & 23.00 & $27.16 \pm 2.02$ & $47.83 \pm 2.84$ & $38.09 \pm 1.62$ & 37.69 \\
\hline $\mathrm{NH}_{3}{ }^{-} \mathrm{N}(\mathrm{mg} / \mathrm{L})$ & $0.57 \pm 0.03$ & $2.44 \pm 0.04$ & $1.38 \pm 0.02$ & 1.46 & $0.32 \pm 0.03$ & $1.23 \pm 0.02$ & $0.85 \pm 0.04$ & 0.80 \\
\hline TSS (mg/L) & $43.26 \pm 0.35$ & $73.17 \pm 0.82$ & $41.65 \pm 0.46$ & 52.69 & $53.86 \pm 1.68$ & $85.03 \pm 3.63$ & $45.98 \pm 0.65$ & 61.62 \\
\hline As $(\mu \mathrm{g} / \mathrm{L})$ & $2.42 \pm 6.13 \mathrm{E}-05$ & $3.38 \pm 3.30 \mathrm{E}-05$ & $3.74 \pm 6.24 \mathrm{E}-05$ & 3.18 & $2.57 \pm 2.55 \mathrm{E}-05$ & $6.94 \pm 4.85 \mathrm{E}-05$ & $6.54 \pm 3.69 \mathrm{E}-05$ & 5.35 \\
\hline $\mathrm{Cd}(\mu \mathrm{g} / \mathrm{L})$ & $1.30 \pm 1.63 \mathrm{E}-05$ & $8.81 \mathrm{E}-01 \pm 1.21 \mathrm{E}-05$ & $1.50 \pm 6.11 \mathrm{E}-05$ & 294.60 & $1.16 \pm 2.77 \mathrm{E}-05$ & $7.70 \pm 1.84 \mathrm{E}-04$ & $3.51 \mathrm{E}-01 \pm 1.73 \mathrm{E}-06$ & 119.95 \\
\hline $\mathrm{Cr}(\mu \mathrm{g} / \mathrm{L})$ & $2.85 \pm 3.51 \mathrm{E}-05$ & $2.84 \pm 2.95 \mathrm{E}-05$ & $2.28 \pm 3.15 \mathrm{E}-05$ & 2.66 & $5.93 \mathrm{E}-01 \pm 4.33 \mathrm{E}-05$ & $1.24 \pm 1.67 \mathrm{E}-05$ & $1.09 \pm 2.52 \mathrm{E}-05$ & 198.44 \\
\hline $\mathrm{Cu}(\mu \mathrm{g} / \mathrm{L})$ & $11.70 \pm 6.11 \mathrm{E}-05$ & $7.86 \pm 4.61 \mathrm{E}-05$ & $11.80 \pm 1.30 \mathrm{E}-05$ & 10.456 & $11.40 \pm 2.57 \mathrm{E}-05$ & $15.70 \pm 1.10 \mathrm{E}-04$ & $8.77 \pm 1.50 \mathrm{E}-05$ & 11.96 \\
\hline $\mathrm{Fe}(\mu \mathrm{g} / \mathrm{L})$ & $7.23 \mathrm{E} 02 \pm 4.60 \mathrm{E}-04$ & $1.18 \mathrm{E} 02 \pm 8.94 \mathrm{E}-04$ & $1.40 \mathrm{E} 02 \pm 4.24 \mathrm{E}-04$ & 1101.00 & $7.46 \mathrm{E} 02 \pm 9.45 \mathrm{E}-03$ & $5.36 \mathrm{E} 02 \pm 2.25 \mathrm{E}-03$ & $5.14 \mathrm{E} 02 \pm 7.07 \mathrm{E}-04$ & 3748.67 \\
\hline $\mathrm{Mn}(\mu \mathrm{g} / \mathrm{L})$ & $31.30 \pm 4.11 \mathrm{E}-04$ & $77.80 \pm 1.73 \mathrm{E}-02$ & $87.90 \pm 5.13 \mathrm{E}-05$ & 65.67 & $31.60 \pm 2.14 \mathrm{E}-05$ & $65.90 \pm 1.11 \mathrm{E}-04$ & $56.00 \pm 9.42 \mathrm{E}-05$ & 51.17 \\
\hline $\mathrm{Ni}(\mu \mathrm{g} / \mathrm{L})$ & $3.46 \pm 1.06 \mathrm{E}-04$ & $4.66 \pm 1.80 \mathrm{E}-05$ & $4.10 \pm 2.95 \mathrm{E}-05$ & 4.07 & $3.27 \pm 1.40 \mathrm{E}-05$ & $3.59 \pm 2.65 \mathrm{E}-05$ & $3.32 \pm 5.13 \mathrm{E}-06$ & 3.39 \\
\hline $\mathrm{Pb}(\mu \mathrm{g} / \mathrm{L})$ & $9.57 \pm 3.04 \mathrm{E}-04$ & $7.11 \pm 3.21 \mathrm{E}-05$ & $12.30 \pm 1.91 \mathrm{E}-05$ & 9.66 & $9.60 \pm 1.90 \mathrm{E}-05$ & $9.94 \pm 3.95 \mathrm{E}-05$ & $10.2 \pm 2.36 \mathrm{E}-05$ & 9.91 \\
\hline $\mathrm{Zn}(\mu \mathrm{g} / \mathrm{L})$ & $4.10 \mathrm{E} 02 \pm 1.02 \mathrm{E}-04$ & $1.47 \mathrm{E} 02 \pm 1.97 \mathrm{E}-04$ & $2.19 \mathrm{E} 02 \pm 1.57 \mathrm{E}-04$ & 258.67 & $3.85 \mathrm{E} 02 \pm 5.17 \mathrm{E}-03$ & $1.53 \mathrm{E} 02 \pm 2.49 \mathrm{E}-04$ & $1.60 \mathrm{E} 02 \pm 1.66 \mathrm{E}-04$ & 232.67 \\
\hline
\end{tabular}

*dissolved oxygen (DO), chemical oxygen demand (COD), biochemical oxygen demand ( $\left.\mathrm{BOD}_{5}\right)$, total suspended solids (TSS), ammoniacal nitrogen ( $\mathrm{NH} \mathrm{H}_{3} \mathrm{~N}$ ), arsenic (As), cadmium $(\mathrm{Cd})$, chromium $(\mathrm{Cr})$, iron $(\mathrm{Fe})$, manganese $(\mathrm{Mn})$, lead $(\mathrm{Pb})$, zinc $(\mathrm{Zn})$ and nickel $(\mathrm{Ni})$ 
On average, the conventional rice value was 1.24 greater than the organic rice value. $\mathrm{pH}$ values for conventional rice fields were greater than those observed for the water samples in organic rice fields due to the application of urea in the conventional rice field. The application of urea in agriculture leads to increased pH (Whalen et al., 2000; Liu et al., 2010). Among conventional rice samples, sample $\mathrm{S} 2$ exhibited the lowest $\mathrm{pH}$ as the sampling point was located in the rice field, which was related to the decay by stagnant water in the rice field (Lee et al., 2015). $\mathrm{pH}$ values reported herein were comparable with those (pH 5.51-5.99) reported previously by Lee et al., (2015). The $\mathrm{pH}$ values recorded for water were within the permissible range for irrigation purposes as specified by the DOE.

Average ranges of DO recorded for conventional and organic rice were $4.15 \pm 0.14 \mathrm{mg} / \mathrm{L}$ to $6.57 \pm 0.29 \mathrm{mg} / \mathrm{L}$ and $3.45 \pm 0.45 \mathrm{mg} / \mathrm{L}$ to $5.46 \pm 0.41 \mathrm{mg} / \mathrm{L}$, respectively (Table 3). Based on the NWQS for Malaysia, the average DO for conventional rice was categorized into class II, while the average DO for organic rice was categorized into class III. Hence, the recorded DO values of water are within the permissible range for irrigation and fishery purposes as specified by the DOE, Malaysia. Results obtained from the independent sample t-test revealed that significant differences are observed between conventional and organic rice $(\mathrm{p}<0.05)$. On average, the conventional rice value was 1.08 greater than the organic rice value. Among conventional rice samples, sample $\mathrm{S} 2$ exhibited the highest mean $\mathrm{DO}$ value, while among organic rice samples, sample T2 exhibited the highest mean DO value due to the location of both samples S2 and T2 in the rice field. Adequate DO is a major indicator for good water quality as DO is crucial for the survival of aquatic organisms. Ariffin et al. (2019) have reported that aquatic life experiences stress if the water oxygen levels drop to less than $5.00 \mathrm{mg} / \mathrm{L}$, and some fish species (e.g., catfish and tilapia) require a minimum DO of $3.00 \mathrm{mg} / \mathrm{L}$ for survival. The DO value for conventional rice was greater than that for organic rice due to the depletion of oxygen water by organic materials used in rice farming (Xu et al., 2017). Al-Shami et al. (2010) have reported that DO values for rice fields are greater due to the photosynthesis by algal populations. Moreover, the strong wind and shallow water of rice fields lead to high water turbulence, leading to rich DO (Frei and Becker, 2005; Nugraheni, 2017; Sule et al., 2018).

Table 3 shows the average ranges of $\mathrm{BOD}_{5}$ recorded for conventional and organic rice were $1.16 \pm 0.32 \mathrm{mg} / \mathrm{L}$ to $2.48 \pm 0.11 \mathrm{mg} / \mathrm{L}$ and $0.62 \pm 0.35 \mathrm{mg} / \mathrm{L}$ to $1.44 \pm 0.19 \mathrm{mg} / \mathrm{L}$, respectively. Based on the NWQS, the average $\mathrm{BOD}_{5}$ for conventional rice was categorized into class II, while the average $\mathrm{BOD}_{5}$ for organic rice was categorized into class I. Hence, the recorded $\mathrm{BOD}_{5}$ values of water are within the permissible range for irrigation and fishery purposes as specified by the DOE, Malaysia. Results obtained from the independent sample t-test revealed a significant difference between conventional and organic rice $(\mathrm{p}<0.05)$. On average, the conventional rice value was 0.65 greater than the organic rice value. The $\mathrm{BOD}_{5}$ values for conventional rice were greater than those for organic rice due to the fertilization activity. The highest $\mathrm{BOD}_{5}$ values were observed for 
sample S2 (conventional rice) and sample T2 (organic rice) due to their sampling location in the rice field. During the cultivation phase, the $\mathrm{BOD}_{5}$ value increased due to the decay process as well as other contributors such as the fertilizer application, which increased the organic content of water bodies (Hanafiah et al., 2018c). Ariffin et al. (2019) have reported that the nutrient content of chemical fertilizers can lead to the increase in the microorganisms in water, thereby contributing to the high $\mathrm{BOD}_{5}$ values.

Average ranges of COD recorded for conventional and organic rice were $11.45 \pm 3.48 \mathrm{mg} / \mathrm{L}$ to $29.88 \pm 0.32 \mathrm{mg} / \mathrm{L}$ and $27.16 \pm 2.02 \mathrm{mg} / \mathrm{L}$ to $47.83 \pm 2.84 \mathrm{mg} / \mathrm{L}$, respectively (Table 3). Based on the NWQS, the average COD for conventional rice was categorized into class II, while the average COD for organic rice was categorized into class III. Hence, the recorded COD values of water are within the permissible range for irrigation and fishery purposes as specified by the DOE, Malaysia. Results obtained from the independent sample t-test revealed a significant difference between conventional and organic rice $(\mathrm{p}<0.01)$. On average, the organic rice value was 14.69 greater than the conventional rice value. The COD values for organic rice were greater than those for conventional rice due to the level of organic matter resulting from the organic fertilization of the organic rice field (Ahmad et al., 2014).

Average ranges of $\mathrm{NH}_{3}-\mathrm{N}$ recorded for conventional and organic rice were $0.57 \pm 0.03 \mathrm{mg} / \mathrm{L}$ to $2.44 \pm 0.04 \mathrm{mg} / \mathrm{L}$ and $0.32 \pm 0.03 \mathrm{mg} / \mathrm{L}$ to $1.23 \pm 0.02 \mathrm{mg} / \mathrm{L}$, respectively (Table 3). Based on the NWQS, the average $\mathrm{NH}_{3}-\mathrm{N}$ for conventional rice was categorized into class IV, while the average $\mathrm{NH}_{3}-\mathrm{N}$ for organic rice was categorized into class I. Hence, the recorded $\mathrm{NH}_{3}-\mathrm{N}$ values of water are within the permissible range for irrigation and fishery purposes as specified by the DOE, Malaysia. Results obtained from the independent sample t-test revealed a significant difference between conventional and organic rice $(\mathrm{p}<0.05)$. On average, the conventional rice value was greater than the organic rice value by 0.66 . $\mathrm{NH}_{3}-\mathrm{N}$ values for conventional rice were greater than those for organic rice due to the high application of urea in the conventional rice field. The decay of discharged organic waste in water can lead to the increase in the ammonia concentration (Li et al., 2008; Asman et al., 2017). Yang et al. (2017) have reported that a high $\mathrm{pH}$ value for the conventional rice field leads to a high ammoniacal nitrogen value as $\mathrm{pH}$ can increase the rate of dissolved ammonia available for volatilization.

Average ranges of TSS recorded for conventional and organic rice were $41.65 \pm 0.46 \mathrm{mg} / \mathrm{L}$ to $73.17 \pm 0.82 \mathrm{mg} / \mathrm{L}$ and $45.98 \pm 0.65 \mathrm{mg} / \mathrm{L}$ to $85.03 \pm 3.63 \mathrm{mg} / \mathrm{L}$, respectively as shown in Table 3. Based on the NWQS, the average TSS results for conventional rice and organic rice were categorized into class III. Hence, the recorded TSS values of water are within the permissible range for irrigation and fishery purposes as specified by the DOE, Malaysia. Results obtained from the independent sample t-test revealed no significant differences between conventional and organic rice $(p>0.05)$. On average, the organic rice value was 8.93 greater than the conventional rice value. The nature of the muddy condition of rice fields as well as cultivation activities such as ploughing have contributed to high TSS (Al-Shami et al., 2010). Moreover, the 
application of organic fertilizers in the organic rice field has increased the density of phytoplankton, thereby contributing to the increase in the TSS (Ahmed et al., 2013).

Results obtained from the independent sample t-test revealed a significant difference between conventional and organic rice for $\mathrm{As}, \mathrm{Fe}$, and $\mathrm{Ni}(\mathrm{p}<0.01)$ and $\mathrm{Cr}$ was $\mathrm{p}<0.001$. On average, the organic rice values for $\mathrm{As}$ and $\mathrm{Fe}$ were greater than the conventional rice values by 0.02 and 2.65 , respectively. On the other hand, the average conventional rice values for $\mathrm{Ni}$ and $\mathrm{Fe}$ were greater than the organic rice values by 0.01 and 0.02 , respectively. Harun and Hanafiah (2018a) have reported that the application of chemical fertilizers in the rice field leads to the increase in the heavy metal concentration. Notably, the organic rice field in this study was previously implementing conventional rice cultivation practices. Hence, similar results for heavy metals are observed for conventional and organic rice fields. The highest concentration of Fe was observed in the conventional and organic rice fields. Iron toxicity in lowland rice fields was related to the flooded condition and pesticide application during cultivation (Fageria, 2007).

Nutrients lost from the rice cultivation phase contaminate water bodies. Hence, concerns over the water quality of rice fields have increased in recent decades. The obtained results revealed that the WQI for conventional and organic rice is categorized into class III based on the WQI classification by the DOE, Malaysia. Hence, the WQI is suitable for irrigation and fishery activities. However, for water supply purposes, extensive water treatment needs to be conducted (Halim et al., 2017; Manikam et al., 2019). The results obtained herein were similar to those previously obtained by Ahmad et al. (2014) and Haque et al. (2010). In conclusion, the conventional rice cultivation in the examined rice field follows the permissible rate of fertilizer and pesticide applications. The results obtained herein can serve as a guideline for the future water quality management in rice field studies.

\section{Physicochemical analysis of soil}

Physicochemical analysis of soil for conventional and organic rice fields was performed according to parameters such as $\mathrm{pH}, \mathrm{SOM}, \mathrm{EC}$, particle size distribution, and heavy metal analysis. Table 4 summarizes the results obtained.

Average ranges of $\mathrm{pH}$ recorded for conventional and organic rice were $5.13 \pm 0.02$ to $5.30 \pm 0.01$ and $4.20 \pm 0.10$ to $4.43 \pm 0.06$, respectively (Table 4). Results obtained from the independent sample t-test revealed a significant difference between conventional and organic rice $(\mathrm{p}<0.001)$. On average, the conventional rice value was 0.86 greater than the organic rice value. The results obtained herein were comparable with those obtained by Aishah et al. (2010) and Khairiah et al. (2009), with the soil pH ranges within 4.63-5.14 and 4.5-5.0, respectively. In addition, the soil $\mathrm{pH}$ values for rice cultivation recommended by MARDI were within the $\mathrm{pH}$ range of 5.5-6.5 (Aishah et al., 2010). 
Table 4. Physicochemical analysis of soil

\begin{tabular}{|c|c|c|c|c|c|c|c|c|}
\hline \multirow{2}{*}{ Parameter } & \multicolumn{4}{|c|}{ Conventional rice } & \multicolumn{4}{|c|}{ Organic rice } \\
\hline & P1 & $\mathbf{P 2}$ & $\mathbf{P 3}$ & $\mathbf{P}_{\text {average }}$ & Q1 & Q2 & Q3 & Qaverage \\
\hline $\mathrm{pH}$ & $5.14 \pm 0.05$ & $5.30 \pm 0.01$ & $5.13 \pm 0.02$ & 5.19 & $4.43 \pm 0.06$ & $4.20 \pm 0.10$ & $4.37 \pm 0.06$ & 4.33 \\
\hline $\operatorname{SOM}(\%)$ & $1.90 \pm 0.02$ & $3.33 \pm 0.15$ & $2.66 \pm 0.12$ & 2.63 & $2.77 \pm 0.15$ & $3.68 \pm 0.16$ & $3.15 \pm 0.05$ & 3.20 \\
\hline $\mathrm{EC}(\mu \mathrm{S} / \mathrm{m})$ & $0.25 \pm 0.02$ & $0.35 \pm 0.03$ & $0.32 \pm 0.01$ & 0.31 & $0.22 \pm 0.01$ & $0.26 \pm 0.01$ & $0.22 \pm 0.01$ & 0.23 \\
\hline Silt (\%) & $65.00 \pm 2.00$ & $62.33 \pm 0.58$ & $56.00 \pm 3.61$ & 61.11 & $59.67 \pm 2.72$ & $68.67 \pm 3.51$ & $63.00 \pm 4.00$ & 63.78 \\
\hline Clay $(\%)$ & $29.00 \pm 1.30$ & $32.00 \pm 4.04$ & $36.67 \pm 5.69$ & 32.56 & $28.81 \pm 1.92$ & $23.00 \pm 4.36$ & $29.00 \pm 6.08$ & 26.94 \\
\hline Sand $(\%)$ & $6.00 \pm 0.44$ & $5.67 \pm 2.00$ & $7.33 \pm 2.65$ & 6.33 & $11.52 \pm 0.52$ & $8.33 \pm 3.21$ & $8.00 \pm 2.18$ & 9.28 \\
\hline As $(\mu \mathrm{g} / \mathrm{L})$ & $31.0 \pm 4.48 \mathrm{E}-05$ & $13.95 \pm 0.01$ & $16.63 \pm 1.30 \mathrm{E}-05$ & 20.5 & $27.49 \pm 1.93 \mathrm{E}-05$ & $40.09 \pm 2.24 \mathrm{E}-05$ & $75.09 \pm 1.08 \mathrm{E}-05$ & 47.57 \\
\hline $\mathrm{Cd}(\mu \mathrm{g} / \mathrm{L})$ & $0.94 \pm 6.25 \mathrm{E}-05$ & $1.45 \pm 5.19 \mathrm{E}-05$ & $0.59 \pm 5.13 \mathrm{E}-06$ & 20.57 & $0.81 \pm 1.31 \mathrm{E}-05$ & $1.39 \pm 0.00$ & $0.21 \pm 8.54 \mathrm{E}-06$ & 0.81 \\
\hline $\mathrm{Cr}(\mu \mathrm{g} / \mathrm{L})$ & $1.7 \mathrm{E} 02 \pm 7.69 \mathrm{E}-05$ & $12.53 \mathrm{E} 01 \pm 4.20 \mathrm{E}-05$ & $1.41 \mathrm{E} 02 \pm 2.02 \mathrm{E}-04$ & 145.65 & $1.40 \mathrm{E} 02 \pm 0.01$ & $1.30 \mathrm{E} 02 \pm 0.00$ & $1.39 \mathrm{E} 02 \pm 5.27 \mathrm{E}-04$ & 136.72 \\
\hline $\mathrm{Cu}(\mu \mathrm{g} / \mathrm{L})$ & $5.4 \mathrm{E} 01 \pm 6.54 \mathrm{E}-05$ & $47.12 \pm 5.43 \mathrm{E}-05$ & $46.427 \pm 6.52 \mathrm{E}-05$ & 49.18 & $50.99 \pm 0.01$ & $46.56 \pm 0.01$ & $37.08 \pm 2.48 \mathrm{E}-05$ & 44.88 \\
\hline $\mathrm{Fe}(\mu \mathrm{g} / \mathrm{L})$ & $11.7 \mathrm{E} 04 \pm 0.01$ & $71.75 \mathrm{E} 03 \pm 0.01$ & $84.99 \mathrm{E} 03 \pm 3.31 \mathrm{E}-04$ & $91.33 \mathrm{E} 03$ & $68.67 \mathrm{E} 03 \pm 51.39$ & $15.27 \mathrm{E} 04 \pm 0.01$ & $25.66 \mathrm{E} 04 \pm 0.01$ & $15.33 \mathrm{E} 04$ \\
\hline $\mathrm{Mn}(\mu \mathrm{g} / \mathrm{L})$ & $5.55 \mathrm{E} 02 \pm 0.002$ & $5.47 \mathrm{E} 02 \pm 8.31 \mathrm{E}-05$ & $3.47 \mathrm{E} 02 \pm 4.67 \mathrm{E}-05$ & 483.00 & $4.90 \mathrm{E} 02 \pm 5.75 \mathrm{E}-05$ & $2.78 \mathrm{E} 02 \pm 9.29 \mathrm{E}-06$ & $2.55 \mathrm{E} 02 \pm 5.77 \mathrm{E}-05$ & 341.20 \\
\hline $\mathrm{Ni}(\mu \mathrm{g} / \mathrm{L})$ & $36.99 \pm 6.29 \mathrm{E}-05$ & $29.09 \pm 4.47 \mathrm{E}-05$ & $28.39 \pm 9.51 \mathrm{E}-05$ & 31.49 & $30.08 \pm 5.44 \mathrm{E}-05$ & $22.86 \pm 4.74 \mathrm{E}-05$ & $24.64 \pm 1.25 \mathrm{E}-05$ & 25.86 \\
\hline $\mathrm{Pb}(\mu \mathrm{g} / \mathrm{L})$ & $2.24 \mathrm{E} 02 \pm 5.9 \mathrm{E}-05$ & $1.92 \mathrm{E} 02 \pm 0.01$ & $2.07 \mathrm{E} 02 \pm 3.68 \mathrm{E}-05$ & 207.67 & $1.99 \mathrm{E} 02 \pm 8.18 \mathrm{E}-05$ & $1.99 \mathrm{E} 02 \pm 2.44 \mathrm{E}-05$ & $2.05 \mathrm{E} 02 \pm 2.13 \mathrm{E}-05$ & 201.33 \\
\hline $\mathrm{Zn}(\mu \mathrm{g} / \mathrm{L})$ & $1.57 \mathrm{E} 02 \pm 4.66 \mathrm{E}-05$ & $1.05 \mathrm{E} 02 \pm 0.01$ & $1.50 \mathrm{E} 02 \pm 5.38 \mathrm{E}-05$ & 137.00 & $1.33 \mathrm{E} 02 \pm 2.55 \mathrm{E}-05$ & $1.33 \mathrm{E} 02 \pm 6.87 \mathrm{E}-05$ & $1.13 \mathrm{E} 02 \pm 5.88 \mathrm{E}-05$ & 126.51 \\
\hline
\end{tabular}

* soil organic matter (SOM), electrical conductivity (EC), arsenic (As), cadmium (Cd), chromium (Cr), iron (Fe), manganese (Mn), lead (Pb), zinc ( $\mathrm{Zn})$ and nickel (Ni) 
In addition, the use of chemical fertilizers has led to the increase in the soil humus, thereby affecting the $\mathrm{pH}$ values (Ahmad et al., 2014). Previously, Angelova et al. (2013), Sarwar et al. (2008) and Smiciklas et al. (2008) have reported that the application of organic fertilizers in rice fields leads to the decrease in the $\mathrm{pH}$ values as the application of organic fertilizers in organic rice field contributes to the production of organic acids such as amino acids and humid acid during the mineralization of organic materials by heterotrophs and nitrification by autotrophs; hence, a low pH is obtained (Sarwar et al., 2008).

Table 4 shows the average ranges of SOM recorded for conventional and organic rice were $1.90 \pm 0.02 \%$ to $3.33 \pm 0.15 \%$ and $2.77 \pm 0.15 \%$ to $2.77 \pm 0.15 \%$, respectively. Results obtained from the independent sample t-test revealed a significant difference between conventional and organic rice $(\mathrm{p}<0.05)$. On average, the SOM of organic rice was 0.57 greater than that of conventional rice. The application of an organic fertilizer leads to a high content of organic matter in the soil (Kushwaha et al., 2001; Selvakumari et al., 2001; Smiciklas et al., 2008). Organic matter plays a key role in binding soil particles; hence, soil strength is enhanced. In addition, high organic matter can contribute to the high productivity (Hasan et al., 2020).

Soil EC is the ability of the soil to transmit an electrical charge (Chan et al., 2008). Average ranges of EC recorded for conventional and organic rice were $0.25 \pm 0.02 \mathrm{mS} / \mathrm{m}$ to $0.35 \pm 0.03 \mathrm{mS} / \mathrm{m}$ and $0.22 \pm 0.01 \mathrm{mS} / \mathrm{m}$ to $0.26 \pm 0.01 \mathrm{mS} / \mathrm{m}$, respectively (Table 4). In this study, EC values were within the range of the suggested EC value $(<2.70 \mathrm{mS} / \mathrm{m})$ for rice cultivation in tropical Asia (MAFF, 1970). Results obtained from the independent sample t-test revealed a significant difference between conventional and organic rice ( $\mathrm{p}<0.01$ ). On average, the conventional rice value was 0.073 greater than the organic rice value. In this study, urea was applied in the conventional rice field. The combination of urea and NPK fertilizers can afford a high EC value (Han et al., 2016). Selvakumari et al. (2001), and Smiciklas et al. (2008) have reported that the reading of EC can increase under acidic and alkaline conditions by the application of organic materials to the soil.

Table 4 shows the particle size distribution percentage. Based on the obtained results, the soil samples contain a high percentage of the silt and clay fraction (grain size $<63 \mu \mathrm{m}$ ) for conventional and organic rice fields. Based on the United States Department of Agriculture (USDA), the type of soil for conventional rice and organic rice herein was classified as silty clay loam and silty clay, respectively. Results obtained from the independent sample t-test revealed no significant difference between silt, clay, and soil for conventional and organic rice ( $p>0.05$ ). Dou et al. (2016) have reported that soil texture as well as the interaction between the water regime and cultivar affect the rice yield. In addition, the high clay soil can contribute to the high yield due to the finer particles of clay soil, which can retain water and nutrients better than sandy soil (Tsubo et al., 2007; Dou et al., 2016; Aboudi Mana et al., 2017).

Results obtained from the independent sample t-test revealed a significant difference $(\mathrm{p}<0.01)$ between conventional and organic rice for As, $\mathrm{Fe}, \mathrm{Ni}$, and $\mathrm{Cr}(\mathrm{p}<0.0001)$. 
Previously, the organic field in this study was practicing conventional rice farming; hence, the difference between the metal results is nearly the same. The use of chemical pesticides can lead to the increase in the heavy metal content of the rice field (Aimrun et al., 2011; Jamil et al., 2011). Results revealed that among the metals tested, the total Fe content was the highest. However, the value was considered to be less than that reported previously by Khairiah et al. (2009), where Fe values ranged from 254 to $379 \mathrm{mg} / \mathrm{kg}$. Jamil et al. (2011) have reported that flooded conditions in rice fields lead to the precipitation of dissolved Fe. Hence, the oxidized condition of Fe can occur as finely grained hydrous oxides $\left(\mathrm{Fe}(\mathrm{OH})_{3}\right)$ with a disordered structure; hence, mixing with clays is possible (Khairiah et al., 2009).

\section{Conclusions}

In this study, the water quality and soil physicochemical characteristics were assessed by laboratory analysis. We found that water quality measured from the organic and conventional rice fields was classified as Class III. Although similar water and soil quality obtained for all sampling stations from both organic and conventional rice fields, organic farming is a better alternative to overcome the environmental contamination that is caused from the constant utilization of chemical fertilizers. However, future study can be done by considering a longer temporal duration of the water and soil quality measurements for a better understanding of the physicochemical characteristics of water and soil in conventional and organic rice fields in Malaysia.

Acknowledgments. Marlia M. Hanafiah was supported by the National University of Malaysia, UKM. This research was funded by UKM Research Grants (DIP-2019-001 and KRA-2018-054) and supported by the Ministry of Education Malaysia (FRGS/1/2018/WAB05/UKM/02/2).

\section{REFERENCES}

[1] Aboudi Mana, S. C., Hanafiah, M. M., Chowdhury, A. J. K. (2017): Environmental Characteristics of Clay and Clay-Based Minerals. - Geology, Ecology, and Landscapes 1: 155-161.

[2] Ahmad, H., Rashid, M. A. A., Ismail, N., Mohamed, N. (2014): Impact of Rice Paddies Plantation Activities on Surface Water Quality in Mukim 5, Seberang Perai Utara, Malaysia. - International Journal of Advances in Agricultural \& Environmental Engineer 1: 2349-1531.

[3] Ahmed, S., Arifur Rahman, A., Hossain, A. (2013): Phytoplankton Biodiversity in Seasonal Waterlogged Paddy Fields, Bangladesh. - Ecologia 1: 1-8.

[4] Aimrun, W., Amin, M., Ezrin, M., Mastura, M. (2011): Paddy Soil Properties and Yield Characteristics Based on Apparent Electrical Conductivity Zone Delineation for a Humid Tropical Rice Farm. - African Journal of Agricultural Research 6: 5339-5350.

[5] Aishah, A., Zauyah, S., Anuar, A., Fauziah, C. (2010): Spatial Variability of Selected Chemical Characteristics of Paddy Soils in Sawah Sempadan, Selangor, Malaysia. Malaysian Journal of Soil Science 14: 27-39. 
[6] Al-Shami, S., Salmah, C., Azizah, M. S., Abu Hassan, A. (2010): The Influence of Routine Agricultural Activities on the Quality of Water in a Tropical Rice Field Ecosystem. Applied Ecology and Environmental Research 8: 11-18.

[7] Al-Shujairi, S. (2013): Develop and Apply Water Quality Index to Evaluate Water Quality of Tigris and Euphrates Rivers in Iraq. - International Journal of Modern Engineering Research 3: 2119-2126.

[8] Alssgeer, H. M. A., Gasim, M. B., Hanafiah, M. M., Abdulhadi, E. R. A., Azid, A. (2018): GIS-Based Analysis of Water Quality Deterioration in the Nerus River, Kuala Terengganu Malaysia. - Desalination and Water Treatment 112: 334-343.

[9] American Public Health Association; American Water Works Association; and Water Environment Federation (1998): Standard Methods for the Examination of Water and Wastewater. $-20^{\text {th }}$ ed., Washington, D.C.

[10] Angelova, V., Akova, V., Artinova, N., Ivanov, K. (2013): The Effect of Organic Amendments on Soil Chemical Characteristics. - Bulgarian Journal of Agricultural Science 19: 958-971.

[11] Ariffin, F., Halim, A. A., Hanafiah, M. M., Awang, N., Othman, M., Azman, S., Bakri, N. (2019): The Effects of African Catfish, Clarias Gariepinus Pond Farm's Effluent on Water Quality of Kesang River in Malacca, Malaysia. - Applied Ecology and Environmental Research 17: 1531-1545.

[12] Ashraf, M. A., Hanafiah, M. M. (2017): Recent Advances in Assessment on Clear Water, Soil and Air. - Environmental Science and Pollution Research 24: 22753-22754.

[13] Asman, N. S., Halim, A. A., Hanafiah, M. M., Ariffin, F. D. (2017): Penentuan Kualiti Air Daripada Sistem Penuaian Air Hujan Di Kolej Ungku Omar, Ukm Bangi. - Sains Malaysiana 46: 1211-1219.

[14] ASTM (2008): Standard Test method for Ammonia Nitrogen in Water, Standard D1426. ASTM International, West Conshohocken, PA.

[15] Avery, B. W., Bascomb, C. L. (1982): Soil Survey Laboratory Methods. - Tech Monograph 6, Soil Survey of England and Wales, Harpenden.

[16] Banch, T. J. H., Hanafiah, M. M., Amr, S. S. A., Alkarkhi, A. F. M., Hasan, M. (2020): Treatment of landfill leachate using palm oil mill effluent. - Processes 8: 601.

[17] Bong, P. X. H., Malek, M. A., Mardi, N. H., Hanafiah, M. M. (2020): Cradle-to-gate waterrelated impacts on production of traditional food products in Malaysia. - Sustainability 12(13): 5274.

[18] Bouman, B. (2007): A Conceptual Framework for the Improvement of Crop Water Productivity at Different Spatial Scales. - Agricultural Systems 93: 43-60.

[19] Champagne, E. T., Bett-Garber, K. L., Grimm, C. C., McClung, A. M. (2007): Effects of Organic Fertility Management on Physicochemical Properties and Sensory Quality of Diverse Rice Cultivars. - Cereal Chemistry 84: 320-327.

[20] Chan, K. Y., Van Zwieten, L., Meszaros, I., Downie, A., Joseph, S. (2008): Agronomic values of greenwaste biochar as a soil amendment. - Soil Research 45: 629-634.

[21] Chapman, H. (1965): Cation-Exchange Capacity 1. Methods of soil analysis. Part 2. Chemical and microbiological properties methods of soil, pp. 891-901.

[22] Department of Statistic Malaysia (DOSM) (2018): Selected Agriculture Indicators, Strategic Communication and International Division. - Department of Statistic Malaysia, Putrajaya, Malaysia.

[23] DOE. (2006): Environmental Quality Report. - Kuala Lumpur, Department of Environment.

[24] Dou, F., Soriano, J., Tabien, R. E., Chen, K. (2016): Soil Texture and Cultivar Effects on Rice (Oryza Sativa L.) Grain Yield, Yield Components and Water Productivity in Three Water Regimes. - PloS one 11: 150-549. 
[25] EPA. (1996): Acid Digestion of Sediments, Sludges and Soils. Method 3050B. Environmental Protection Agency Office of Water, United States.

[26] Fageria, N. (2007): Green Manuring in Crop Production. - Journal of Plant Nutrition 30: 691-719.

[27] Farooq, M., Kobayashi, N., Wahid, A., Ito, O., Basra, S. M. (2009): Strategies for Producing More Rice with Less Water. - Advances in Agronomy 101: 351-388.

[28] Frei, M., Becker, K. (2005): Integrated Rice-Fish Production and Methane Emission under Greenhouse Conditions. - Agriculture, Ecosystems \& Environment 107: 51-56.

[29] Global Environmental Monitoring System (GEMS). (1978): GEMS Water Operational guide. - United Nation Environmental Programme, Geneva.

[30] HACH. (1998): DR/2000 Spectrophotometer Instruments Manual for Use with Software Version 3. - USA, HACH Company.

[31] Haefele, S., Nelson, A., Hijmans, R. J. (2014): Soil Quality and Constraints in Global Rice Production. - Geoderma 235: 250-259.

[32] Halim, A. A., Hanafiah, M. M., Khairi, A. (2017): Ammonia Removal from Sewage Wastewater Using Chemically Modified Sand. - Applied Ecology and Environmental Research 15: 521-528.

[33] Han, S. H., An, J. Y., Hwang, J., Kim, S. B., Park, B. B. (2016): The Effects of Organic Manure and Chemical Fertilizer on the Growth and Nutrient Concentrations of Yellow Poplar (Liriodendron Tulipifera Lin.) in a Nursery System. - Forest Science and Technology 12: 137-143.

[34] Hanafiah, M. M., Yussof, M., Hasan, M., Abdulhasan, M., Toriman, M. E. (2018a): Water Quality Assessment of Tekala River, Selangor, Malaysia. - Applied Ecology and Environmental Research 16: 5157-5174.

[35] Hanafiah, M. M., Nadheer, A. H., Ahmed, S. T., Ashraf, M. A. (2018b): Removal of chromium from aqueous solutions using a palm kernel shell adsorbent. - Desalination and Water Treatment 118: 172-180.

[36] Hanafiah, M. M., Mohamad, N. H. S. M., Aziz, N. I. H. A. (2018c): Salvinia molesta dan Pistia stratiotes sebagai Agen Fitoremediasi dalam Rawatan Air Sisa Kumbahan. - Sains Malaysiana 47(8): 1625-1634.

[37] Hanafiah, M. M., Ghazali, N. F., Harun, S. N., Abdulaali, H. S., AbdulHasan, M. J., Kamarudin, M. K. A. (2019): Assessing water scarcity in Malaysia: A case study of rice production. - Desalination and Water Treatment 149: 274-287.

[38] Hanafiah, M. M., Zainuddin, M. F., Nizam, N. U. M., Halim, A. A., Rasool, A. (2020): Phytoremediation of Aluminum and Iron from Industrial Wastewater using Ipomoea aquatica and Centella asiatica. - Applied Sci. 10: 3064.

[39] Haque, M., Huang, Y., Lee, T. (2010): Seberang Perai Rice Scheme Irrigation Water Quality Assessment. - Journal of the Institution of Engineers Malaysia 71: 42-48.

[40] Harun, S. N., Hanafiah, M. M. (2018a): Blue and green water use of cultivating selected crops in Malaysia. - AIP Conference Proceedings 1940: 020027.

[41] Harun, S., Hanafiah, M. M. (2018b): Estimating the Country-Level Water Consumption Footprint of Selected Crop Production. - Applied Ecology and Environmental Research 16: 5381-5403.

[42] Hasan, M., Hanafiah, M. M., Taha, Z. A., Alhilfy, I. H. H. (2020): Effect of low-intensity laser irradiation on field performance of maize (Zea mays L.) emergence, phenological and seed quality characteristics. - Applied Ecology and Environmental Research 18(4): 60096023.

[43] Hua, A. K. (2015): An Indication of Policy Study Towards Water Resources in Malacca State: A Case Study of Malacca River, Malaysia. - International Research Journal of Social Sciences 4: 15-20. 
[44] Iqbal, M. (2011): Nitrogen Leaching from Paddy Field under Different Fertilization Rates. - Malaysian Journal of Soil Science 15: 101-114.

[45] Jamil, H., Theng, L. P., Jusoh, K., Razali, A. M., Ali, F. B., Ismail, B. (2011): Speciation of Heavy Metals in Paddy Soils from Selected Areas in Kedah and Penang, Malaysia. African Journal of Biotechnology 10: 13505-13513.

[46] Jat, L. K., Singh, Y. V., Meena, S. K., Meena, S. K., Parihar, M., Jatav, H. S., Meena, R. K., Meena, V. S. (2015): Does integrated nutrient management enhance agricultural productivity? - Journal of Pure and Applied Microbiology 9: 1211-1221.

[47] Keawpeng, I., Meenune, M. (2012): Physicochemical Properties of Organic and Inorganic Phatthalung Sungyod Rice. - International Food Research Journal 19: 857.

[48] Khairiah, J., Habibah, H., Anizan, I., Maimon, A., Aminah, A., Ismail, B. (2009): Content of Heavy Metals in Soil Collected from Selected Paddy Cultivation Areas in Kedah and Perlis, Malaysia. - Journal of Applied Sciences Research 5: 2179-2188.

[49] Krawczyk, D., Gonglewski, N. (1959): Determining Suspended Solids Using a Spectrophotometer. - Sewage and Industrial Wastes 31: 1159-1164.

[50] Kushwaha, C., Tripathi, S., Singh, K. (2001): Soil Organic Matter and Water-Stable Aggregates under Different Tillage and Residue Conditions in a Tropical Dryland Agroecosystem. - Applied Soil Ecology 16: 229-241.

[51] Lee, H. J., Jeong, S. E., Kim, P. J., Madsen, E. L., Jeon, C. O. (2015): High Resolution Depth Distribution of Bacteria, Archaea, Methanotrophs, and Methanogens in the Bulk and Rhizosphere Soils of a Flooded Rice Paddy. - Frontiers in Microbiology 6: 639.

[52] Lenka, S., Rajendiran, C. M., Dotaniya, M., Saha, J. (2016): Impacts of Fertilizers Use on Environmental Quality. - National seminar on environmental concern for fertilizer use in future at Bidhan Chandra Krishi Viswavidyalaya, Kalyani.

[53] Leščešen, I., Pantelić, M., Dolinaj, D., Stojanović, V., Milošević, D. (2015): Statistical Analysis of Water Quality Parameters of the Drina River (West Serbia). - Polish Journal of Environmental Studies 24: 11.

[54] Li, H., Liang, X., Chen, Y., Tian, G., Zhang, Z. (2008): Ammonia Volatilization from Urea in Rice Fields with Zero-Drainage Water Management. - Agricultural Water Management 95: 887-894.

[55] Li, H., Shi, Z., Webster, R., Triantafilis, J. (2013): Mapping the Three-Dimensional Variation of Soil Salinity in a Rice-Paddy Soil. - Geoderma 195: 31-41.

[56] Liu, E., Yan, C., Mei, X., He, W., Bing, S. H., Ding, L., Liu, Q., Liu, S., Fan, T. (2010): Long-Term Effect of Chemical Fertilizer, Straw, and Manure on Soil Chemical and Biological Properties in Northwest China. - Geoderma 158: 173-180.

[57] Liu, Y., Yang, M., Wu, Y., Wang, H., Chen, Y., Wu, W. (2011): Reducing $\mathrm{CH}_{4}$ and $\mathrm{CO}_{2}$ Emissions from Waterlogged Paddy Soil with Biochar. - Journal of Soils and Sediments 11: 930-939.

[58] MAFF. (1970): Modern Farming and the Soil. - Report of the Agricultural Advisory Council on Soil Structure and Soil Fertility, HMSO, London.

[59] Manikam, M. K., Halim, A. A., Hanafiah, M. M., Krishnamoorthy, R. R. (2019): Removal of Ammonia Nitrogen, Nitrate, Phosphorus and COD from Sewage Wastewater Using Palm Oil Boiler Ash Composite Adsorbent. - Desalination and Water Treatment 149: 2330.

[60] Meher, P. K., Sharma, P., Gautam, Y. P., Kumar, A., Mishra, K. P. (2015): Evaluation of Water Quality of Ganges River Using Water Quality Index Tool. - Environment Asia 8.

[61] MOA. (2016): Maklumat Perangkaan Industri Padi Dan Beras. - Putrajaya, Malaysia.

[62] Nizam, N. U. M., Hanafiah, M. M., Noor, I. M., Karim, H. I. A. (2020): Efficiency of Five Selected Aquatic Plants in Phytoremediation of Aquaculture Wastewater. - Applied Science 10: 2712. 
[63] Nugraheni, P. (2017): Karakteristik Biofisikokimia Tanah Sawah Dan Hasil Beberapa Varietas Padi Dengan Azolla Dan Biochar. - Tesis, Universitas Sebelas Maret.

[64] Reche, M. H. L., Machado, V., Saul, D. A., Macedo, V. R., Marcolin, E., Knaak, N., Fiuza, L. M. (2016): Microbial, Physical and Chemical Properties of Irrigation Water in Rice Fields of Southern Brazil. - Anais da Academia Brasileira de Ciências 88: 361-375.

[65] Rhee, H., Yoon, C., Son, Y., Jang, J. (2011): Quantitative Risk Assessment for Reclaimed Wastewater Irrigation on Paddy Rice Field in Korea. - Paddy and Water Environment 9: 183-191.

[66] Sarwar, G., Schmeisky, H., Hussain, N., Muhammad, S., Ibrahim, M., Safdar, E. (2008): Improvement of Soil Physical and Chemical Properties with Compost Application in RiceWheat Cropping System. - Pakistan Journal of Botany 40: 275-282.

[67] Selvakumari, G., Santhi, R., Natesan, R., Sathiyabama, K. (2001): Soil Test and Vegetable Crop Response under Integrated Plant Nutrition System for Optimization of Fertilizer Doses. - South Indian Horticulture 49: 130-136.

[68] Singh, V., Singh, A. P., Bhadoria, J., Giri, J., Singh, J., Vineeth, T. V., Sharma, P. C. (2017): Differential expression of salt-responsive genes to salinity stress in salt-tolerant and salt-sensitive rice (Oryza sativa L.) at seedling stage. - Protoplasma 255: 1667-1681.

[69] Smiciklas, K., Walker, P., Kelley, T. (2008): Evaluation of Compost for Use as a Soil Amendment in Corn and Soybean Production. - Compost Science \& Utilization 16: 183191.

[70] Sule, H. A., Ismail, A., Amal, M. N. A., Zulkifli, S. Z., Roseli, M. F. A. M., Shohaimi, S. (2018): Water Quality Influences on Fish Occurrence in Peat Swamp Forest and Its Converted Areas in North Selangor, Malaysia. - Sains Malaysiana 47: 2589-2600.

[71] Thakur, S., Singh, L., Zularisam, A. W., Sakinah, M., Din, M. F. M. (2016): Lead induced oxidative stress and alteration in the activities of antioxidative enzymes in rice shoots. Biologia Plantarum 61: 595-598.

[72] Tsubo, M., Fukai, S., Basnayake, J., Tuong, T. P., Bouman, B., Harnpichitvitaya, D. (2007): Effects of Soil Clay Content on Water Balance and Productivity in Rainfed Lowland Rice Ecosystem in Northeast Thailand. - Plant Production Science 10: 232-241.

[73] USDA. (2018): United States Department of Agriculture National Resources Conservation Service. - The Plants Database, National Plant Data Center, Baton Rouge, LA.

[74] Wang, Y., Dang, F., Evans, R. D., Zhong, H., Zhao, J., Zhou, D. (2016): Mechanistic Understanding of Mehg-Se Antagonism in Soil-Rice Systems: The Key Role of Antagonism in Soil. - Scientific Reports 6: 19-47.

[75] Whalen, J. K., Chang, C., Clayton, G. W., Carefoot, J. P. (2000): Cattle Manure Amendments Can Increase the $\mathrm{pH}$ of Acid Soils. - Soil Science Society of America Journal 64: 962-966.

[76] Yang, J., Zhou, Q., Zhang, J. (2017): Moderate Wetting and Drying Increases Rice Yield and Reduces Water Use, Grain Arsenic Level, and Methane Emission. - The Crop Journal 5: 151-158.

[77] Yisa, J., Jimoh, T. (2010): Analytical Studies on Water Quality Index of River Landzu. American Journal of Applied Sciences 7: 453.

[78] Zhao, K., Fu, W., Ye, Z., Zhang, C. (2015): Contamination and Spatial Variation of Heavy Metals in the Soil-Rice System in Nanxun County, Southeastern China. - International Journal of Environmental Research and Public Health 12: 1577-1594. 